\title{
UPAYA MENGANTISIPASI PERDAGANGAN MANUSIA DITINJAU MENURUT ANTI- TRAFFICKING IN PERSONS ACT, 2007 DAN HUKUM ISLAM
}

\author{
Hajah Makiah Tussaripah binti Jamil \\ Akademi Pengajian Islam Kontemporari (ACIS) \\ Universiti Teknologi Mara (UiTM) Cawangan Negeri Sembilan \\ Kampus Seremban 3, Negeri Sembilan, Malaysia \\ e-mail:makiah@uitm.edu.my
}

\begin{abstract}
We often hear and read about reports of a growing number of trafficking crime cases that are worrisome in almost every corner of the country. Studies show that trafficking crimes make women a target not only of individuals but also a form of conspiracy and malicious co-operation of various parties that form the network internationally. Most trafficked women are victims of fraudulent frauds that lead to them being forced to work without pay and paid as maids and so on. The discussion of this paper will focus on the Anti-Trafficking in Persons Act 2007 (Act 670) which provides for trafficking offenses and protection of victims. Also exemplified is the Islamic view of trafficking crimes which is seen to be at odds with Shariah maqasid and humanitarian values. The proposed proposal then takes into account a more just and equitable approach to Islamic jurisprudence, taking into account the concept of ta'zir that emphasizes the various forms of punishment such as whipping, killing, diyyat and so on which are expected to deal with crime more effectively.
\end{abstract}

Keywords: Human beings, Islam, Ta'zir, Trade

\begin{abstract}
ABSTRAK
Kita sering mendengar dan membaca tentang laporan meningkatnya kejahatan perdagangan manusia dan kecemasan di hampir setiap sudut negara. Studi menunjukkan bahwa kejahatan perdagangan membuat perempuan menjadi target tidak hanya dari individu tetapi juga bentuk konspirasi dan kerjasama jahat dari berbagai pihak yang membentuk jaringan internasional. Sebagian besar perempuan yang diperdagangkan adalah korban penipuan yang menyebabkan mereka dipaksa bekerja tanpa dibayar dan dibayar sebagai pembantu rumah tangga dan sebagainya. Pembahasan makalah ini akan fokus pada Anti-Trafficking in Persons Act 2007 (Act 670) (UU Anti-Perdagangan Orang 2007 (UU 670)) yang mengatur tentang pelanggaran perdagangan dan perlindungan korban. Juga dicontohkan adalah pandangan Islam tentang kejahatan perdagangan manusia yang dipandang bertentangan dengan maqasid Syariah dan nilai-nilai kemanusiaan. Usulan yang diajukan kemudian mempertimbangkan pendekatan yurisprudensi Islam yang lebih adil dan merata, dengan mempertimbangkan konsep ta'zir yang menekankan berbagai bentuk hukuman seperti mencambuk, membunuh, diyyat dan sebagainya yang diharapkan dapat menangani kejahatan dengan lebih efektif.
\end{abstract}

Kata Kunci: Hukum Islam, Manusia, Perdagangan, Ta'zir.

\begin{tabular}{|c|c|c|c|}
\hline FIRST RECEIVED: & REVISED: & ACCEPTED: & PUBLISHED: \\
21 January 2020 & 10 January 2021 & 06 March 2021 & 15 April 2021 \\
\hline
\end{tabular}

\section{PENDAHULUAN}


Sejarah berlalu dan waktu berubah. Tetapi tradisi perbudakan manusia tetap merupakan kanker yang hampir tidak mungkin disembuhkan. Meskipun 'perbudakan modern' ini lahir dalam berbagai bentuk dan versi, ini mengandung semua fitur dan sifat perbudakan. Era modern menyaksikan kejahatan perdagangan manusia sebagai bentuk perbudakan modern yang dialami hampir di setiap negara di dunia.

Perempuan adalah target utama karena kecenderungan digunakan sebagai simbol ketertarikan seksual. Selain diperdagangkan secara seksual dengan dipaksa menjadi pelacur, perempuan juga sangat berharga dan bernilai tinggi karena mereka dianggap identik dengan pekerjaan rumah tangga dan cenderung dipaksa menjadi pembantu rumah tangga.

Tindakan drastis harus diambil oleh semua pihak karena kejahatan perdagangan perempuan bukan hanya satu pihak. Faktanya, ini adalah jaringan kriminal yang sangat luas dan terorganisir yang melibatkan korban, rekrutmen lokal, petugas dan pejabat penegak hukum, pedagang yang tertarik, pemerintah dan sindikat internasional (Vidyamali Samarasinghe, 2008).

Anti-Trafficking in Persons Act 2007 merupakan satu undang-undang di Malaysia bertujuan mengatur pelanggaran perdagangan, perlindungan dan bantuan orang-orang yang diperdagangkan. Undang-undang ini disahkan di Parlemen pada Mei 2007 yang disahkan pada 1 Oktober 2007, di Bagian I, II, ss. 66 dan 67 (lihat P.U (B) 338/2007) dan pada 28 Februari 2008, untuk Bagian III, IV, V dan VI (lihat P.U. (B) 86/2008). Undang-undang ini terdiri dari 67 bagian dan dibagi menjadi 6 bagian utama (Dimulainya, Dewan Anti-
Trafficking, Pelanggaran Perdagangan Orang, Penegakan, Perlindungan dan Perlindungan Trafiking dan Lain-lain) diharapkan memberikan mekanisme perbaikan yang lebih efektif untuk menangani masalah ini.

Islam adalah agama yang sempurna dan adil yang memberikan pedoman dan jalan untuk menangani masalah ini. Apa bentuk hukuman dan hukum Islam yang berlaku untuk penjahat perdagangan perempuan? Apakah hukuman yang ada dan yang dipraktikkan di sebagian besar negara cukup dan dapat mengendalikan situasi ini? Semua pertanyaan ini akan dibahas dan dibahas sehingga kami dapat mengusulkan dan menghasilkan bentuk resolusi dan metode yang lebih baik dan lebih adil sesuai dengan aturan yang telah ditetapkan Islam.

\section{METODE PENELITIAN}

Penelitian ini menggunakan metode kualitatif dan memperoleh data berupa literatur serta jurnal yang membahas tentang masalah perdagangan manusia. Fokus pembahasannya adalah pada UU Anti-Trafficking in Persons 2007 (UU 670) yang mengatur tentang tindak pidana trafiking dan perlindungan korban. Peneliti kemudian melihat perdebatan dan pandangan Islam tentang kejahatan perdagangan manusia yang dinilai sejalan dengan tuntutan syariah dan nilai-nilai kemanusiaan.

\section{HASIL DAN PEMBAHASAN}

Hasil penelitian ini kemudian diterjemahkan menjadi beberapa debat dan perbahasan di bawah sub judul berikut:

\section{Definisi Perdagangan Manusia}


Kamus Fajar (Hornby \& Asmah, tt) memberikan definisi 'perdagangan' sebagai bentuk perdagangan ilegal dan tidak bermoral. Ini berarti bahwa setiap orang yang terlibat dalam kejahatan perdagangan ini dianggap bersalah atas beberapa bentuk pelanggaran hukum dan moral dan dapat dikenakan hukuman perdata dan pidana oleh pemerintah.

Konferensi Perserikatan BangsaBangsa (No. 49/166) memberikan definisi perdagangan sebagai gerakan ilegal dan rahasia orang untuk melintasi perbatasan di dalam atau di luar negara terutama dari negaranegara berkembang dan negara-negara yang sedang dalam transisi (Chairul Bariah Mozasa, 2005). Tujuan utamanya adalah untuk memaksa perempuan dan anak-anak ke dalam penindasan dan eksploitasi seksual dan ekonomi untuk kepentingan perekrut (agen), pedagang manusia dan sindikat kriminal. Situasi ini mirip dengan kegiatan ilegal lainnya yang terkait dengan perdagangan manusia seperti gadis-gadis yang dipaksa, pernikahan palsu, tenaga kerja ilegal dan adopsi yang tidak sah.

\section{Jenis Dan Tujuan Perdagangan Manusia}

Perdagangan dapat terjadi karena alasan dan tujuan tertentu. Fenomena 'trafiking' menunjukkan bahwa hampir semua perempuan yang diperdagangkan dipaksa untuk bekerja secara paksa. Di banyak negara seperti Arab Saudi, Iran dan Indonesia, perempuan dipaksa bekerja sebagai pembantu rumah tangga, di pabrik dan pertanian. Energi mereka akan terbuang sia-sia dan tidak dibayar seperti yang dijanjikan. Kerja paksa terjadi ketika energi seseorang dipaksakan oleh intimidasi, kekerasan, tekanan, penipuan, penyalahgunaan kekuasaan dan posisi dan beban atau beban hutang (Ronald, 2014). Sering kali, dokumen penting seperti paspor akan disimpan dan disembunyikan oleh majikan untuk tujuan perempuan tidak dapat melarikan diri atau mencari bantuan.

Pelacuran dan perdagangan seks adalah agenda dan tujuan utama ketika seorang perempuan diperdagangkan. Pelacuran adalah suatu bentuk aktivitas seksual yang berada di luar praktik pernikahan yang menjadikan seks atau aktivitas seksual lainnya sebagai motif dan tujuan. Seseorang yang bersedia menjadi pelacur menjadikan pembayaran dan faktor uang sebagai tujuan utama mereka dalam kegiatan tersebut. Dalam kasus seperti itu mereka sering mengabaikan emosi dan naluri yang sebenarnya. Berbeda dengan perempuan yang terjebak, ditipu dan diperdagangkan untuk tujuan pelacuran. Mereka dipaksa untuk melacurkan diri dan melayani pelanggan mereka hanya karena mereka diancam atau diancam dengan sesuatu yang lebih besar.

Sindikat perdagangan juga mengekspos perempuan yang telah menjadi korban perdagangan narkoba. Biasanya wanita ini digunakan sebagai perantara yang membawa atau mendistribusikan obat-obatan dari satu tempat ke tempat lain. Kita sering mendengar wanita atau gadis muda ditangkap oleh pihak berwenang karena membawa atau mendistribusikan narkoba. Mereka sering menjadi korban dan diperas oleh penjahat sungguhan untuk membebaskan diri dari pihak berwenang. Wanita miskin yang menjadi korban itu akhirnya dihukum mati karena kejahatan yang terpaksa mereka lakukan.

$$
\text { Perdagangan juga biasanya }
$$
tersembunyi di balik agen perjodohan yang tumbuh seperti jamur. Konsep populer 'mempelai pesanan melalui pos' di kalangan 
gadis-gadis muda sebenarnya telah membawa mereka ke kehidupan yang lebih menyedihkan. Ketika mereka dikirim sebagai pengantin, mereka sering dipaksa bekerja sebagai pembantu rumah tangga tanpa upah dan diperlakukan sebagai budak. Misalnya, dilaporkan bahwa dari tahun 1987 hingga 1997, 41\% orang Filipina yang beremigrasi ke Amerika dianggap sebagai 'mempelai wanita'. Meskipun beberapa wanita berhasil membuat hidup mereka lebih baik, sebagian besar hidup mereka akhirnya menjadi pelacur atau pekerja paksa.

Di banyak negara berkembang, misalnya Malaysia, telah menjadi 'tren' bahwa kita dapat melihat semakin banyak pusat pendidikan tinggi swasta di hampir setiap negara bagian. Dari sudut pandang positif, sangat baik dalam mempromosikan kelanjutan dari tuntutan pengetahuan. Di sisi lain, sindikat perdagangan perempuan juga dapat terjadi dengan menggunakan tempat studi ini untuk menyembunyikan identitas mereka yang sebenarnya. Wanita yang direkrut atau dikirim ke sini terkadang menggunakan visa sebagai pelajar asing untuk memasuki negara tersebut. Setelah tiba di negara itu, mereka akan dipaksa untuk melakukan pelacuran dan terlibat dalam perdagangan seks tanpa persetujuan.

\section{Fakta dan Data}

Definisi 'perdagangan manusia' yang diberikan oleh Konferensi PBB menyatakan bahwa kejahatan ini berasal dari negara-negara dunia ketiga atau negara-negara berkembang. Kejahatan ini memberikan indikasi bahwa resesi dan kemiskinan adalah faktor utama dalam perdagangan manusia (Laczko \& Gozdiak, 2005). Resesi ekonomi dunia dan inflasi yang tinggi telah menjadi pendorong meningkatnya angka kemiskinan di banyak negara terbelakang dan berkembang. Menurut data Statistik Pusat Indonesia (CPS), tingkat kemiskinan pada tahun 1996 meningkat sebesar 11,3\% menjadi 23,4\% pada tahun 1999 (Chairul, 2006).

Kondisi kehidupan yang sangat buruk menghalangi pendidikan lebih lanjut. Penemuan perdagangan seks telah menjadi cara termudah dan tercepat untuk mencari nafkah. Kemiskinan juga menyebabkan banyak perempuan dan ibu keluar dari jalan mereka untuk mencari pekerjaan dan meninggalkan anak-anak terlantar dan berisiko tinggi menjadi korban sindikat perdagangan manusia. Mayoritas dari mereka datang ke Malaysia untuk mencari peluang ekonomi yang lebih besar daripada di negara asalnya dan situasi ini memudahkan mereka untuk terlibat dengan masalah perdagangan manusia (Norcikeyonn \& Nor-Ina, 2013).

Studi tersebut juga menemukan bahwa masalah perdagangan manusia juga terjadi di kawasan Asia Tenggara, terutama di sebagian besar negara berkembang. Tuntutan hidup akibat kerawanan ekonomi, perkembangan sosial, politik nasional yang tidak stabil, dan minimnya paparan pendidikan telah mengakibatkan banyak daerah pedesaan di negara-negara berisiko tinggi ini menjadi sasaran fenomena perdagangan manusia (Firdaus \& Zarina, 2015).

Ketika kemiskinan terlalu ketat untuk kehidupan, ia memaksa seseorang untuk meminjam sehingga hutang tidak dapat diselesaikan

. Ketika ini terjadi, kreditor yang sebenarnya adalah agen perekrutan yang akan memaksa orang tua atau keluarga untuk 
menyerahkan anak perempuan mereka untuk bekerja untuk membayar hutang. Keluarga mungkin tidak mengharapkan anak mereka dilecehkan atau dipaksa menjadi pekerja. Untuk orang Filipina, biaya migrasi mereka ke suatu negara menggunakan dokumen perjalanan atau izin kerja palsu sangat tinggi. Akibatnya, mereka dipaksa bekerja selama beberapa tahun di industri seks untuk membayar hutang mereka kepada perekrut yang membawa mereka ke negara itu.

Upaya untuk mencegah dan memberantas tidak akan ada artinya tanpa dukungan sistem penegakan yang bersih dan dapat dipercaya. Pihak berwenang terutama di antara polisi harus benar-benar berusaha memberantas kejahatan ini dan tidak menjadi dalang di balik penjahat. Misalnya, ada laporan bahwa perempuan Bengal atau Burma yang diperdagangkan di Pakistan bernilai antara US1.500 hingga 2.500 per orang tergantung pada usia, penampilan, dan keperawanan mereka (perawan). Untuk setiap wanita yang dijual, polisi yang tidak jujur yang menerima suap menuntut komisi 15 hingga 20 persen.

Oleh karena itu, selain masalah korupsi di kalangan penegak hukum, kelemahan dalam sistem hukum juga merupakan faktor dalam kriminalisasi perdagangan perempuan.

\section{Angka Perdagangan Wanita di Malaysia}

Menurut direktur Departemen Investigasi Kriminal Datuk Christopher Wan Wan, setidaknya 20 negara di dunia telah diidentifikasi sebagai "negara sumber" dari para tersangka pekerja seks yang ditangkap di Malaysia. Menurut dia, tingkat kenaikan ratarata 20 hingga 25 persen per tahun, jumlah penahanan tertinggi antara 2000 dan 2007 adalah warga negara dari Indonesia diikuti oleh China, Thailand dan Filipina. Warga dari
Rusia, India, Myanmar dan Uzbekistan menunjukkan penurunan pada tahun yang sama (Arul, 2007).

Korban sindikat perdagangan manusia di Malaysia sering kali ditipu dengan janji bekerja sebagai pembantu rumah tangga atau pekerja di sektor makanan atau pabrik. Mereka dijanjikan gaji yang layak dan tempat yang nyaman. Di sisi lain, ketika mereka tiba di Malaysia, mereka akan dijemput oleh agen atau agen yang menjanjikan pekerjaan dan dibawa ke pusat prostitusi untuk diperdagangkan. Seringkali paspor mereka dirahasiakan atau disembunyikan dan diancam dengan kekerasan atau tindakan oleh pihak berwenang. Namun, ada kasus-kasus perempuan Malaysia diselundupkan ke luar negeri untuk tujuan eksploitasi seksual tetapi jumlahnya terlalu kecil.

Menurut Datuk Christopher Wan, di Malaysia, sulit untuk menentukan jumlah pasti atau perkiraan orang yang diselundupkan keluar atau masuk ke Malaysia. Ini karena jumlah imigran ilegal hampir mencapai 4\% dari populasi Malaysia. Sindikat penyelundupan hanya menghadapi risiko kecil dan menuai manfaat besar dengan memanfaatkan sejumlah besar imigran potensial. Perempuan yang diselundupkan dari satu negara sekarang dibandingkan dengan perempuan dari negara lain di dunia.

Di banyak negara termasuk Malaysia, sebagian besar wanita yang ditangkap akan dianggap penjahat dan dipenjara karena prostitusi atau imigran ilegal. Pejuang hak asasi manusia sering membuat masalah ini yang perlu diperbaiki karena kelompokkelompok ini tidak boleh diperlakukan atau diperlakukan sebagai penjahat, tetapi harus 
diperlakukan dan dilindungi sebagai korban (Heli, 2007).

Atas dasar itu, pemerintah Malaysia yang bersangkutan telah menyetujui tindakan khusus yang diharapkan dapat mengatasi masalah perdagangan perempuan dan anakanak sembari menyediakan media perlindungan yang memadai bagi para korban.

\section{Peraturan Perundang-undangan Tentang Perdagangan Manusia di Malaysia}

Di antara ketentuan hukum yang melindungi perempuan dan anak-anak dari kejahatan perdagangan orang adalah Pasal 6, Konstitusi (Perlembagaan Persekutuan) yang menetapkan larangan semua bentuk dan jenis yang memaksakan kerja paksa. Selain itu, pasal 366, 367, 370, dan 371 Kanun Keseksaan (UU 574) mengatur hukuman bagi penculikan perempuan untuk tujuan pelacuran.

Bagian 366 dan 367 mengatur tentang larangan dan hukuman atas pelanggaran memperkosa atau menculik wanita dengan maksud untuk memaksa mereka melakukan hubungan seks pranikah atau dipaksa untuk hidup sebagai pelacur harus dihukum penjara untuk jangka waktu hingga 10 tahun dan juga dapat dihukum dengan denda.

Selain itu, Bagian 370 dan 371 juga menjatuhkan hukuman kepada siapa saja yang melakukan pelanggaran mengimpor, mengekspor, mentransfer, membeli, menjual, menerima dan menahan siapa pun sebagai budak di mana bertentangan dengan kehendaknya hukuman maksimum 7 tahun dan denda. Jika orang tersebut melakukan pelanggaran, ia dapat dihukum maksimal 20 tahun penjara dan denda. Dalam situasi ini, jelas terlihat bahwa perbudakan dan kerja paksa merupakan bentuk perdagangan manusia yang dilarang keras, termasuk di Malaysia (Zuraini dan Khairul Azmin, 2013).

Anti-Trafficking in Persons Act 2007 (Act 670), Bagian 12 menetapkan hukuman untuk perdagangan anak-anak non-kecil dengan tujuan dan tujuan eksploitasi, hukuman penjara tidak lebih dari 15 tahun dan juga dapat dihukum dengan denda. Jika pelanggaran dilakukan dengan unsur-unsur ancaman, kekerasan, penyimpangan, penyalahgunaan kekuasaan serta unsur-unsur memberi atau menerima tunjangan dan pembayaran kepada orang-orang yang mengendalikan orang-orang yang diperdagangkan, maka hukuman maksimumnya adalah 20 tahun penjara dan denda.

Yang menarik adalah bahwa undangundang tersebut juga memberikan hukuman penjara maksimum 15 tahun dan denda antara RM50.000 dan RM500.000 bagi mereka yang mendapat manfaat dari perdagangan orang. Bagian V dari Undang-Undang ini mengatur tentang perlindungan dan perlindungan orangorang yang diperdagangkan. Menurut ayat 44 (2) kekuasaan Hakim untuk mengeluarkan perintah penahanan sementara (IPO) untuk seseorang yang ditempatkan di penampungan selama 14 hari untuk tujuan penyelidikan.

Setelah penerbitan perintah IPO, seorang petugas penegak hukum akan menyelidiki kasus ini dan jika orang tersebut adalah korban perdagangan orang berdasarkan undang-undang ini, Hakim berwenang untuk membuat Perintah Perlindungan PO berdasarkan ayat 51 (3). Jika orang tersebut adalah warga negara atau penduduk tetap Malaysia, jangka waktu perlindungan tidak lebih dari 2 tahun. Sedangkan untuk warga negara asing, periode adalah 3 bulan dan setelah itu akan dirilis ke imigrasi dan tindakan 
yang diambil berdasarkan ketentuan UndangUndang Imigrasi 1959/63. Melalui ketentuan Undang-Undang ini, perempuan yang diperdagangkan tidak lagi dianggap penjahat tetapi diperlakukan dan dilindungi sebagai korban.

\section{Perdagangan Manusia Dalam Tinjauan Hukum Islam}

Di dunia jahiliyah Arab, perempuan menjadi alat pertukaran dan perdagangan. Bahkan, ada banyak jenis pernikahan pada masa itu yang menggambarkan posisi perempuan sebagai sesuatu yang bisa dipertukarkan sesuka hati (Ashgar, 1992). Islam datang dengan memberi orang hak dan standar yang sama. Manusia yang diciptakan Tuhan terdiri dari pria dan wanita. Wanita telah diciptakan oleh Tuhan dalam bentuk yang unik dengan karakteristik khusus yang berbeda dari pria, baik di dalam maupun di dalam, secara fisik, mental atau emosional (Wan Ali, 2007).

$$
\text { Islam juga menekankan konsep }
$$
keselamatan pribadi (haqq al-amn) untuk setiap manusia. Ini berarti hak seseorang untuk hidup dalam damai tanpa rasa takut akan kekerasan, penahanan dan penindasan yang melanggar hukum. Hak ini tidak hanya fisik, tetapi termasuk properti dan kehormatan (Muhammad Abdel Halem, 2003).

Perempuan yang diperdagangkan adalah sesuatu yang sangat bertentangan dengan prinsip-prinsip Islam. Ini karena Islam menempatkan manusia pada posisi sebagai makhluk yang sangat mulia. Firman Allah SWT

"Kami telah menciptakan umat manusia dengan cara sebaik mungkin (dan dilengkapi sesuai dengan keadaan mereka)" (al-Qur'an, At-Tiin 95:4)

Manusia adalah ciptaan yang paling sempurna. Tidak benar bagi satu orang untuk menindas dan menindas orang lain demi kepentingan mereka sendiri (Mohammad Hashim Kamali, 1999).

Firman Tuhan

"... dan jangan melanggar (dengan memulai perang); karena Allah tidak menyukai orangorang yang melampaui batas atau melampaui batas" (al-Qur'an, al-Baqarah 2:190).

Yurisprudensi syariah dan Islam diuraikan dan ditetapkan oleh Allah atas dasar mempertahankan 5 keutamaan dalam kehidupan manusia. 5 keutamaan ini juga dikenal sebagai dhoruriyatul khomsah atau maqasid al-syar'iyyah yaitu untuk melindungi kepentingan agama, kehidupan, martabat atau garis keturunan, properti, dan kecerdasan manusia (Wan Ali, 2005).

Misalnya, kehormatan pribadi dan keluarga harus dijaga. Seseorang dilarang melukai diri sendiri dan keluarga. Tidak hanya itu, harga diri seseorang juga perlu dipertahankan baik atas kehendak individu atau sebaliknya (Norraiha, 2016).

Secara umum, dapat dikatakan bahwa kejahatan perdagangan manusia tidak dicakup oleh kejahatan hudud atau qisas. Tidak ada bukti spesifik yang menyatakan bentuk hukumannya dalam Islam. Hukuman untuk kesalahan ini termasuk dalam kategori ta'zir.

Terminologi bahasa berarti penolakan dan pencegahan, atau bantuan. Hukuman tidak secara khusus ditugaskan. Hakim atau pemerintah memiliki hak dan wewenang untuk menentukan jenis-jenis hukuman yang dapat dipilih berdasarkan kejahatan yang dilakukan, sesuai dengan keadaan pelaku, catatan 
kriminalnya, dan keadaan psikologisnya (Jamila, 1999). Namun, Islam memberikan dasar untuk mendefinisikan hal-hal yang menjadi kepentingan umum dan semua tindakan yang diambil tidak boleh bertentangan dengan hukum Islam dan prinsipprinsip umum hukum Islam.

Berbagai jenis hukuman ta'zir dalam Islam datang dalam berbagai bentuk. Beberapa dari mereka adalah tentang tubuh, seperti hukuman mati atau cambuk, beberapa dalam bentuk pembatasan kebebasan seperti penjara atau deportasi negara atau wilayah, dan beberapa dalam bentuk properti dan sebagainya (Paizah, 1996).

Jenis hukuman berikutnya untuk ta'zir adalah jenis hukuman yang merupakan properti. Misalnya dengan denda atau kerusakan dan penyitaan properti. Utusan Allah (semoga damai besertanya) berkata, "Siapa pun yang mengambil sesuatu wajib membayar ganti rugi dan hukuman."

Untuk jenis hukuman berikutnya, ini termasuk mencambuk, mati, diasingkan atau diperingatkan. Beberapa hukuman ini mungkin separah hudud dan qisas, dan pemerintah diberdayakan untuk menentukan hukuman berdasarkan faktor-faktor tertentu. Juga perlu untuk menjatuhkan hukuman bahkan di luar tingkat hudud dan qisas jika dianggap perlu dan tidak dapat dihindari untuk menjaga kesejahteraan rakyat. Sebaliknya, jenis hukuman ini dapat dikategorikan sebagai hukuman untuk kejahatan ta'zir.

Namun, dalam kasus-kasus tertentu di mana para penjahat ini tidak hanya memperdagangkan perempuan, tetapi juga terlibat dalam kasus perzinaan, pembunuhan atau cedera, hukumannya akan berbeda. Menurut hukum syariah, mereka tidak bertanggung jawab untuk dihukum karena 'perdagangan orang', tetapi dapat dikenakan hadd atau qisas berdasarkan jenis pelanggaran yang dilakukan.

\section{SIMPULAN}

Perdagangan manusia adalah kejahatan yang tidak hanya melanggar keselamatan publik tetapi juga melanggar hak individu. Sebagian besar ketentuan hukum yang ada seperti yang ada di Malaysia menjatuhkan hukuman penjara dan hukuman untuk kejahatan ini. Dapat disimpulkan bahwa, meskipun tidak ada hukuman khusus yang ditentukan oleh Islam, hukuman yang digariskan oleh pemerintah tidak bertentangan dengan hukum Islam tetapi dapat dikategorikan sebagai hukuman ta'azir.

Namun, hukuman mati berdasarkan syariah Islam adalah berkah terbesar bagi pemerintah untuk menetapkan langkah hukum yang paling cocok untuk mengekang kejahatan yang sedang berlangsung ini. Ini karena fleksibel dan dapat disesuaikan dengan kebutuhan dan keadaan manusia.

Sebagai contoh, penulis menganggap bahwa harus ada hukuman berat seperti hukuman mati, terutama untuk penjahat berat atau kepala sindikat karena mereka merasa hukuman penjara tidak menjamin penghentian kejahatan karena dapat dilakukan oleh banyak pengikut mereka. Selain denda yang dikenakan, manfaatnya mungkin terbatas hanya untuk pemerintah dan negara. Tentu saja, hukuman juga harus diberikan kepada para korban untuk mengkompensasi penderitaan yang telah mereka derita begitu lama.

Meskipun beberapa orang merasa bahwa kompensasi atau ganti rugi dapat 
diajukan oleh korban jika kasusnya dibawa ke tindakan sipil, agak sulit untuk dilakukan. Ini karena sebagian besar wanita yang menjadi korban ini sebagian besar tidak berpendidikan dan sebagian lagi buta huruf. Untuk mencegah hal ini terjadi, penulis menyarankan bahwa akan lebih baik jika ketentuan untuk kompensasi ditempatkan langsung dalam tindakan yang ada. Ini membuatnya lebih mudah dan menjamin kesejahteraan para korban.

Selain itu, hukuman tidak hanya terbatas pada mereka yang melakukan kejahatan 'perdagangan manusia' ini, tetapi mereka yang berlangganan atau mendapatkan layanan juga harus dikenakan tindakan. Misalnya, mereka yang berlangganan pelacur yang diperdagangkan ini harus didakwa dengan perzinahan jika terbukti bersalah. Untuk pelaku kekerasan dalam rumah tangga, korban kekerasan dalam rumah tangga bertanggung jawab atas qisas untuk tingkat cedera. Secara tidak langsung itu akan menciptakan ketakutan dan kemarahan di antara mereka yang mengambil keuntungan dan mengambil manfaat dari kejahatan ini.

Kesimpulannya, tidak ada yang mustahil untuk dilakukan dalam menangani dan menyelesaikan masalah perdagangan manusia dan perempuan khususnya. Yang lebih penting adalah komitmen dan upaya bersama dari setiap pihak untuk menyelesaikan kejahatan ini. Semua pihak, termasuk individu, orang tua, keluarga, komunitas, media massa, penegak hukum, pemimpin dan jaringan internasional harus sadar dan bekerja sama dengan cara yang memanfaatkan mereka sendiri.

Apa yang dilakukan Nabi Muhammad juga harus menjadi panduan. Ada beberapa upaya yang dilakukan oleh Nabi Muhammad untuk memerangi perdagangan manusia atau lebih dikenal dengan perbudakan di masa awal Islam dengan mengangkat darjat dan status mereka sebagaimana orang normal dan memperlakukan mereka dengan baik. Nabi turut memotivasi sahabat untuk berlomba memerdekakan hamba, mengancam mereka yang melakukan penjualan orang dan mensyaratkan untuk merdekakan hamba sebagai mekanisme bagi menebus dosa (Niki Alma Febriana Fauzi, 2017).

Masalah perdagangan manusia tidak bisa diabaikan di Malaysia dan seluruh dunia karena akan memiliki banyak efek negatif, terutama mengganggu perkembangan politik, ekonomi dan sosial negara (Amirah, Nooraini \& Aishah, 2018).

\section{DAFTAR PUSTAKA}

Ab Hamid, Z., \& Mokhtar, K. A. (2013). Human trafficking: The international, Malaysian legal framework and shariah perspectives. IIUM Law Journal, 21 (2).

Abdel Haleem, M., Sherif, A.O. \& Daniels, K. (2003). Criminal justice in Islam, judicial procedure in the shari'a. London: I.B Tauris.

Akta Anti Pemerdagangan Orang (2007) (Akta 670) (Anti-trafficking in Person Act 2007)

Ali, A. (1992). The rights of women in Islam. Kuala Lumpur: IBS Buku Sdn Bhd.

Askola, H. (2007). Legal responses to trafficking in women for sexual exploitation in the European Union. North America: Hart Publishing.

Fauzi, N.A.F. (2017). Islam dan human trafficking (Upaya nabi dalam melawan 
praktik human trafficking pada masa awal Islam). Muwazah: Jurnal Kajian Gender, 9 (2), 88-105.

Gozdziak, E. M., \& Collett, E. A. (2005). Research on human trafficking in North America: A review of literature. International Migration, 43(1-2), 99-128.

Hamzah, N.A., Othman, N. \& Musa, W.A. (2018). Pemerdagangan manusia di Malaysia: Isu dan pandangan Islam. Jurnal Penyelidikan Islam dan Kontemporari (JOIRC), 2(2), 13-25.

Hornby, A.S., \& Omar, A. (t.t). Oxford Fajar, Advanced Learner's English-Malay Dictionary. Kuala Lumpur: Penerbit Fajar Bakti Sdn Bhd.

Hussain, J. (1999). Islamic law and society An introduction. The Federation Press.

Ismail, P. (1996). Undang-undang jenayah Islam. Kuala Lumpur: Dewan Bahasa dan Pustaka.

Kamali, M.H. (1999) The dignity of man, the Islamic perspective. Malaysia: Ilmiah Publishers, United Kingdom: The Islamic Foundation.

Misran, F., \& Othman, Z. (2015). Migrasi dan keselamatan insan: Kajian kes pemerdagangan kanak-kanak di Thailand. KRITIS: Jurnal Ilmu Sosial dan Ilmu Politik Universitas Hasanuddin, 1(1), 1-23.

Mohamad Eusof, N. (2016). Jenayah pemerdagangan orang dan penyeludupan migran di Malaysia: Pandangan undangundang dan Islam. (Tesis Sarjana). Akademi Pengajian Islam, Universiti Malaya.
Mozasa, C.B. (2005). Aturan-aturan hukum trafiking (Perdagangan perempuan dan anak). USU Press.

Rajoo, D.A. (2007, Oktober 16), Pekerja seks dari 20 negara ditahan di Malaysia. Bernama.com.

Report of the Human Rights Commission of Malaysia (SUHAKAM). (2004) Trafficking in women and children. Malaysia: SUHAKAM.

Samarasinghe, V. (2008). Female sex trafficking in Asia, the resilience of patriarchy in a changing world. New York: Routledge Taylor and Franchise Group.

Samuni, N., \& Kanyo, N. I. (2013). Usaha Malaysia dalam membanteras jenayah pemerdagangan orang: Satu tinjauan. International Journal of Environment, Society and Space (IJESS), 1(1), 62-74.

Wan Jusoh, W.L., Rashid, M.H., \& Yusof, M.F. (2005). Institusi-institusi Islam. Kuala Lumpur: Syarikat Meza.

Wan Jusoh, W.L., Rashid, M.H., Ismail, M.Z., Mustaffa, Z. \& Nasri, Z. (2007). Tasawwur Islam. Kuala Lumpur: UTM City campus.

Weitzer, R. (2014). New directions in research on human trafficking. The ANNALS of the American Academy of Political and Social Science, 653(1), 6-24. 
